\title{
THE EVOLVING EU ANTI-MONEY LAUNDERING REGIME
}

\section{Challenges for Fundamental Rights and the Rule of Law}

\author{
Valsamis Mitsilegas ${ }^{*}$ and Niovi Vavoula ${ }^{* *}$
}

\begin{abstract}
Over the past twenty-five years, the European Union has developed a far-reaching legal regime aimed at countering money laundering. The evolution of this regime has been linked inextricably with the parallel development of global standards in the field, most notably by the Financial Action Task Force on Money Laundering (FATF). This article will critically evaluate the content of EU anti-money laundering law, by putting forward a comprehensive typology of the EU anti-money laundering regime as outlined in the successive EU Anti-Money Laundering Directives and consisting of three elements: the criminalization of money laundering and terrorist finance; the prevention of money laundering via the imposition of a series of duties on the private sector; and the focus on financial intelligence, via the establishment and co-operation of financial intelligence units responsible for receiving and analysing reports received from the private sector. The article will examine the evolution of EU law as regards all elements of anti-money laundering law, by focusing in particular on the changes brought forward by the post-Lisbon Fourth Money Laundering Directive. The article will cast light on the influence of the FATF in shaping these standards and will highlight the impact of the ever expanding EU antimoney laundering legal framework on fundamental rights and the rule of law.
\end{abstract}

Keywords: European criminal law; financial intelligence units; fundamental rights and the rule of law; money laundering and terrorist finance; tax evasion

\footnotetext{
* Professor of European Criminal Law, Director of the Criminal Justice Centre and Head of the Department of Law, Queen Mary University of London.

** Research Assistant in the Department of Law, Queen Mary University of London.
} 


\section{\$1. INTRODUCTION}

Over the past twenty-five years, the European Union has developed a far-reaching legal regime aimed at countering money laundering. The evolution of this regime has been linked inextricably with the parallel development of global standards in the field, most notably by the Financial Action Task Force on Money Laundering (FATF). This article will critically evaluate the content of EU anti-money laundering law, by putting forward a comprehensive typology of the EU anti-money laundering regime as outlined in the successive EU Anti-Money Laundering Directives (AML Directives) ${ }^{1}$ and consisting of three elements: the criminalization of money laundering and terrorist finance; the prevention of money laundering via the imposition of a series of duties on the private sector; and the focus on financial intelligence, via the establishment and co-operation of financial intelligence units responsible for receiving and analysing reports received from the private sector.

The article will examine the evolution of EU law as regards all elements of anti-money laundering law, by focusing in particular on the changes brought forward by the postLisbon Fourth Money Laundering Directive. The article will cast light on the influence of the FATF in shaping these standards and highlight the impact of the ever expanding EU anti-money laundering legal framework on fundamental rights and the rule of law.

\section{\$2. AN EVOLVING LEGAL FRAMEWORK SHAPED BY GLOBALIZATION}

In examining the evolution of EU anti-money laundering law, it is essential to bear in mind that the development of standards in the field reflects a remarkable combination of global and regional standard-setting efforts. The European Union has been active in a number of international fora producing international treaties in the field, most notably in the United Nations (the main treaties being the Vienna Convention in 1988, focusing on the laundering of the proceeds of drug trafficking, and the Convention on Transnational

1 Council Directive 91/308/EEC of 10 June 1991 on prevention of the use of the financial system for the purpose of money laundering, [1991] OJ L 166/77 (the first AML Directive); Directive 2001/97/ EC of the European Parliament and of the Council of 4 December 2001 amending Council Directive 91/308/EEC on prevention of the use of the financial system for the purpose of money laundering, [2001] OJ L 344/76 (the second AML Directive); Directive 2005/60/EC of the European Parliament and of the Council of 26 October 2005 on the prevention of the use of the financial system for the purpose of money laundering and terrorist financing (Text with EEA relevance), [2005] OJ L 309/15 (the third AML Directive); Directive (EU) 2015/849 of the European Parliament and of the Council of 20 May 2015 on the prevention of the use of the financial system for the purposes of money laundering or terrorist financing, amending Regulation (EU) No 648/2012 of the European Parliament and of the Council, and repealing Directive 2005/60/EC of the European Parliament and of the Council and Commission Directive 2006/70/EC (Text with EEA relevance), [2015] OJ L 141/73 (the fourth AML Directive). 
Organised Crime, or the Palermo Convention, of 2000) and in the Council of Europe. ${ }^{2}$ However, even more central to the development of the EU anti-money laundering legal framework has been the work of the Financial Action Task Force (FATF). ${ }^{3}$

The FATF is an ad hoc body, established by the G7 in 1989 under the auspices of the OECD. ${ }^{4}$ Its membership is selective, including OECD states at first and expanding since then to include 'strategically important' countries and largely to reflect financial globalization. ${ }^{5}$ When looking at FATF membership today, it is striking that all 15 'old' EU Member States, along with the Commission, are now full FATF members. However, none of the 12 Member States which joined the EU in 2004 and 2007 is a FATF member (they are all members of MONEYVAL - the Committee of Experts on the Evaluation of Anti-Money Laundering Measures, established in 1997 under the auspices of the Council of Europe). This piecemeal membership means that the Union's executive, the European Commission, can have an influence together with certain Member States, in the shaping of FATF standards and ensuring compliance with these standards, but that participation in regional fora such as the Council of Europe is equally important for the EU in order to put forward a further layer of compliance with global standards - with MONEYVAL benchmarks are not limited to Council of Europe standards but also include FATF, UN and $E U$ anti-money laundering standards. ${ }^{6}$

The main normative output of the FATF has been a series of Recommendations, evolving over time and covering a wide range of aspects of the fight against money laundering. The 40 FATF Recommendations produced in 1990 were revised in 1996, 2003 and 2012, with money laundering counter-measures being deemed necessary to counter a series of emerging and new threats, from drug trafficking to organized crime to terrorism. ${ }^{7}$ The revisions of the FATF Recommendations have gone hand in hand

2 See V. Mitsilegas, 'The European Union and the Globalisation of Criminal Law', 12 Cambridge Yearbook of European Legal Studies 2009-2010 (2010), p. 337-407.

3 V. Mitsilegas, 'Global Governance of Crime "The European Union and the Global Governance of Crime"', in V. Mitsilegas, P. Alldridge and L. Cheliotis (eds.), Globalisation, Criminal Law and Criminal Justice. Theoretical, Comparative and Transnational Perspectives (Hart, 2015), p. 153-198, whereupon this section draws.

4 For a detailed analysis of the role and work of the FATF, see B. Gilmore, Dirty Money: The Evolution of International Measures to Counter Money Laundering and the Financing of Terrorism (4th edition, Council of Europe Publishing, 2011), Ch. 4-6. Gilmore characterizes the FATF as an 'ad hoc grouping of governments and others with a complex but highly focused agenda', ibid., p. 92.

5 The current membership criteria include, along with compliance with FATF standards, 'strategic importance': see FATF, FATF Membership Policy, www.fatf-gafi.org/pages/aboutus/ membersandobservers/fatfmembershippolicy.html.

$6 \quad$ V. Mitsilegas, 'Regional Organisations and the Suppression of Transnational Crime', in N. Boister and S. Currie (eds.), Routledge Handbook on Transnational Criminal Law (Routledge, 2014), p. 73-89.

7 See V. Mitsilegas, 'Countering the Chameleon Threat of Dirty Money: "Hard" and "Soft" Law in the Emergence of a Global Regime against Money Laundering and Terrorist Finance', in A. Edwards and P. Gill (eds.), Transnational Organised Crime: Perspectives on Global Security (Routledge, 2003), p. 195211. 
with the renewal and gradual expansion of the FATF mandate to now include action against money laundering, the financing of terrorism and now proliferation. ${ }^{8}$

The rapid evolution and expansion in the FATF mandate, standards and membership can be attributed to its informal nature ${ }^{9}$ and network structure which aims at flexibility and adaptability. ${ }^{10}$ Although the FATF output takes the form of Recommendations which could be characterized as 'soft law',1' their influence on the development of EU antimoney laundering law has been considerable. All EU anti-money laundering directives have been justified as necessary to implement FATF Recommendations in the European Union legal order. ${ }^{12}$ This strategy has contributed in particular to the extension of the scope of the EU anti-money laundering framework. The first AML Directive served primarily to introduce the preventive framework of the FATF Recommendations into EU law. ${ }^{13}$ The second AML Directive was justified by the Commission as necessary to implement (and go beyond) the revised FATF Recommendations of $1996 .{ }^{14}$ Both main changes introduced by the Directive (namely the extension of the money laundering predicate offences and the extension of preventive duties to non-financial professions) were justified by reference to FATF findings and requirements: the Preamble to the Directive stated that there has been a trend in recent years towards a much wider definition of money laundering based on a broader range of predicate underlying offences, as reflected for example in the 1996 revision of the 40 Recommendations of the Financial Action Task Force, the leading international body devoted to the fight against money laundering. ${ }^{15}$

$8 \quad$ Financial Action Task Force Mandate (2012-2020), Washington DC, 20 April 2012.

9 On the concept of informal international law-making see J. Pauwelyn, R. Wessel and J. Wouters (eds.), Informal International Lawmaking (Oxford University Press, 2012); Informal law-making is defined as dispensing with certain formalities traditionally linked to international law having to do with output, process, or the actors involved, see J. Pauwelyn, 'Informal International Lawmaking: Framing the Concept and Research Questions', in J. Pauwelyn, R. Wessels and J. Wouters (eds.), Informal International Lawmaking (Oxford University Press, 2012), p. 13-34, 15.

10 On the network nature of the FATF see A.-M. Slaughter, A New World Order (Princeton University Press, 2004). Slaughter highlights the advantages of what she calls 'government networks', marrying hard and soft power and using information, persuasion and socialization, see ibid., p. 168 et seq.

11 In the context of the FATF, it can be argued that the regular revision of both mandate and standards has been easier compared to a more formal international organization. See in this context A. Boyle, 'Some Reflections on the Relationship of Treaties and Soft Law', 48 International and Comparative Law Quarterly (1999), p. 901, 903, noting that soft law instruments are easier to amend or replace than treaties.

12 See V. Mitsilegas, Money Laundering Counter-Measures in the European Union: A New Paradigm of Security Governance versus Fundamental Legal Principles (Kluwer Law International, 2003); and V. Mitsilegas and B. Gilmore, 'The EU legislative framework against money laundering and terrorist finance: A critical analysis in the light of evolving global standards', 56 International and Comparative Law Quarterly (2007), p. 119-141.

13 V. Mitsilegas, Money Laundering Counter-Measures in the European Union.

14 Commission Proposal for a European Parliament and Council Directive amending Council Directive 91/308/EEC of 10 June 1991 on prevention of the use of financial system for the purpose of money laundering, COM(1999) 352 final, p 3.

15 Recital 7 of the second AML Directive. 
The Commission also accepted that there is a trend towards the increased use by money launderers of non-financial businesses as confirmed by the work of the FATF on money laundering techniques and typologies. ${ }^{16}$ On the basis of these findings, the second AML Directive extended the list of predicate offences and the list of professions to be covered by the Directive obligations, to include inter alia lawyers. ${ }^{17}$ The third Money Laundering Directive, adopted in 2005, extended the scope of the legislation to cover the fight against terrorist finance, a key political priority post-9/11, and updated existing legislation in the light of international regulatory developments in the field, most notably regarding customer identification. ${ }^{18}$ The Directive presented a major overhaul of the provisions on prevention - in particular those provisions on customer identification - in the light of the revised FATF Recommendations in the field, introducing a number of FATF-inspired concepts such as the so-called 'risk-based approach' to customer identification and more detailed provisions on beneficial ownership and 'politically exposed persons.' ${ }^{19}$

Ensuring compliance with the FATF Recommendations has also been the driver for the negotiation and adoption of the fourth AML Directive: The Commission's Explanatory Note to its proposal for the fourth AML Directive argues that 'a revision of the Directive at this time is complementary to the revised FATF Recommendations, which in themselves represent a substantial strengthening of the anti-money laundering and combating terrorist financing framework'. ${ }^{20}$ The need to align EU law to the revised FATF Recommendations is also reflected in the Preamble to the fourth AML Directive. Recital 4 states that:

Money laundering and terrorist financing are frequently carried out in an international context. Measures adopted solely at national or even at Union level, without taking into account international coordination and cooperation, would have very limited effect. The measures adopted by the Union in that field should therefore be compatible with, and at least as stringent as, other actions undertaken in international fora. Union action should continue to take particular account of the FATF Recommendations and instruments of other international bodies active in the fight against money laundering and terrorist financing. With a view to reinforcing the efficacy of the fight against money laundering and terrorist financing, the relevant Union legal acts should, where appropriate, be aligned with the International Standards on Combating Money Laundering and the Financing of Terrorism and Proliferation adopted by the FATF in February 2012 (the 'revised FATF Recommendations').

\section{Ibid., Recital 14}

17 Human rights concerns with regard to fair trial rights by the European Parliament have led to negotiations on the Directive being extended to the Conciliation stage - agreement was reached after the Directive was packaged as an emergency counter-terrorism measure in the weeks after 9/11. For an overview, see V. Mitsilegas, Money Laundering Counter-measures in the European Union.

18 See Recital 5 of Directive 2005/60/EC for reference to the revision of the FATF Recommendations.

19 For further details and an overview of the third Money Laundering Directive, see V. Mitsilegas and B. Gilmore, 56 International and Comparative Law Quarterly (2007).

20 Commission Proposal for a Directive on the prevention of the use of the financial system for the purpose of money laundering including terrorist financing, $\operatorname{COM}(2013) 45$ final, p. 3. 
The influence of the FATF on the shaping of EU law is also evident in the Commission's impact assessment accompanying the proposal for the fourth AML Directive, according to which one of the key 'problem drivers' is that the existing EU rules are inconsistent with the recently revised international anti-money laundering standards and explains that there is a strong incentive on jurisdictions to correct inconsistencies with the international standards. Full compliance can send an important reputational signal which is vital for countries seeking to attract foreign investment. On the other hand non-compliance is subject to an attentive follow-up process by the FATF. Persistent noncompliance can lead to inclusion in one of the FATF's Public Statements on political and reputational damage. ${ }^{21}$

The influence of FATF standards on the development of EU anti-money laundering law raises a number of rule of law concerns. FATF standards have been developed by a single-agenda ad hoc body with selective membership and a minimum level of transparency and accountability in its operations. ${ }^{22}$ The operation of the FATF in these terms serves to depoliticize the discussion on the need for new anti-money laundering measures which increasingly strengthen the arm of the state and to produce an expert orthodoxy in terms of both money laundering typologies and the necessary measures to counter the phenomenon. ${ }^{23}$ The need for the extension and renewal of both the FATF and its Recommendations has been constantly been accepted as a given, ${ }^{24}$ and each

21 Commission Impact Assessment accompanying the proposal for a Directive on the prevention of the use of the financial system for the purpose of money laundering including terrorist financing and the proposal for a Regulation on information accompanying transfers of funds, SWD(2013) 21 final, p. 18.

22 For a general analysis of the transparency and accountability deficit, relevant also in the context of the FATF, see J. Cohen and C.F. Sabel, 'Global Democracy?', 37 NYU Journal of International Law and Policy (2004-2005), p. 763. They note that 'to a substantial and growing extent, then, rulemaking directly affecting the freedom of action of individuals, firms, and nation states (and the making of the rules to regulate this rulemaking) is taking place, undemocratically but not entirely unaccountably, in global settings created by the world's nations but no longer under their effective control' (ibid., p. 764).

23 On various aspects of the 'depoliticisation' in the development of global standards, see: A. Somek, 'Administration without Sovereignty', University of Iowa Legal Studies Research Paper 09-04 (2009), http://papers.ssrn.com/sol3/papers.cfm?abstract_id=1333282, p. 17 (noting that 'where "problemsolving" serves as the preferred descriptor of an activity, ideological conflict does not enter the picture. Problem-solving is the antithesis of political struggle'); J. Klabbers, 'Institutional Ambivalence by Design: Soft Organizations in International Law', 70 Nordic Journal of International Law (2001), p. 403, (noting that 'the facility of doing business without being side-tracked or controlled, dovetails neatly with our late-modern (or postmodern) infatuation for management and technocracy as viable substitutes for politics'); and D. Kennedy, 'Challenging Expert Rule: The Politics of Global Governance', 27 Sydney Law Review (2005), p. 5 (talking inter alia about 'the expert consensus'). For a more positive view, see A.M. Slaughter, A New World Order (Princeton University Press, 2004), p. 54. Slaughter views the FATF typologies as 'important opportunities for operational experts to identify and describe current money laundering trends and effective countermeasures' and stresses the benefits of professional socialization. Slaughter promotes the advantages of what she calls 'government networks', marrying hard and soft power and using information, persuasion and socialization (ibid., p. 168 et seq.).

24 Kennedy notes in this context that progress narratives become policy programs, 'both by solidifying a professional consensus and by defining what counts as progress for the international governance system as a whole' (D. Kennedy, 27 Sydney Law Review (2005), p. 25). 
production or revision of the FATF Recommendations has been mostly adopted without criticism by the European Commission in its proposals for Union law in the field and subsequently by Member States in the Council and by the European Parliament as colegislators. In this manner, a specific agenda developed by technocrats and with limited scrutiny at the global level has been legitimized, via the EU decision-making process, and adopted at the Union level to bind both FATF and non-FATF members.

\section{\$3. THE CRIMINALIZATION OF MONEY LAUNDERING}

A key component of the EU's anti-money laundering strategy has been in line with global developments in the field - the creation of a series of new money laundering offences. The first AML Directive introduced in the EU legal order gives a definition of money laundering largely following the standard wording of the 1988 Vienna Convention on drug trafficking. ${ }^{25}$ The definition of the main elements of money laundering has remained the same since. What has evolved over time has been the extension - again in line with global developments in the field - of the money laundering predicate offences, namely the crimes which are deemed to generate proceeds for the purposes of EU antimoney laundering law. The extension of the list of predicate offences mirrors the analysis of money laundering as a chameleon threat evolving over time. ${ }^{26}$

Indeed, in line with FATF policy, ${ }^{27} \mathrm{EU}$ law has moved from the prohibition of money laundering of the proceeds of drug trafficking (to address the priorities of the so-called 'war on drugs' in the late 1980s and early 1990s) to move in subsequent decades towards the prohibition of the laundering of the proceeds of organized and serious crime (to address the threat of organized crime), and, post-9/11, and notwithstanding the substantial differences between the two offences, ${ }^{28}$ to add terrorist finance to the EU money laundering prohibition regime. ${ }^{29}$ As will be seen below, the fourth AML Directive adds to the proliferation of this list by expressly requiring Member States to treat tax offences as predicate offences. This expansive approach raises a number of questions regarding the observance of the principle of legality at EU level and the extent to which legislative and policy choices in the fields may lead to uncritical over-criminalization. ${ }^{30}$

V. Mitsilegas, Money Laundering Counter-measures in the European Union, Ch. 3 and 4.

V. Mitsilegas, in A. Edwards and P. Gill (eds.), Transnational Organised Crime: Perspectives on Global Security, p. 195-211.

27 See FATF Recommendations 3 and 5.

28 The main differences between money laundering and terrorist finance involve: the sums involved; the fact that money laundering refers to crimes already committed whereas terrorist finance is forward looking; and the fact that, unlike money laundering, terrorist finance may not involve proceeds of crime (on the latter point see V. Mitsilegas, in A. Edwards and P. Gill (eds.), Transnational Organised Crime: Perspectives on Global Security).

29 V. Mitsilegas and B. Gilmore, 56 International and Comparative Law Quarterly (2007), p. 119-141.

30 On the concept of overcriminalization see D. Husak, Overcriminalization. The Limits of the Criminal Law (Oxford University Press, 2007). 


\section{A. THE EUROPEAN LEGALITY DIMENSION}

A key rule of law question in the adoption of EU money laundering law has been the choice of legal basis. Legal basis questions emerged at the time of the negotiations of the first AML Directive. This was in 1990, before the Maastricht Treaty, which conferred for the first time upon the European Union the express competence to legislate in criminal matters, entered into force. Arguably money laundering legislation is predominantly of a criminal law nature and the primary objective is to combat crime: finding a legal basis in the pre-Maastricht EC Treaty raised legality concerns in view of the limits of Community competence to adopt legislation on criminal offences and sanctions. The solution reached was to adopt the first AML Directive under a dual free movement/internal market legal basis under the justification that preventing money laundering was essential to ensure the integrity of the Community financial system and the internal market. ${ }^{31}$ This solution was combined with a choice of wording in the first AML Directive which obliged Member States to prohibit (rather than criminalize) money laundering.

In practice, all Member States treated the money laundering conduct defined in the first AML Directive within their criminal law, establishing new money laundering offences. Notwithstanding the express conferral upon the European Union of competence to define criminal offences and impose criminal sanctions after the Maastricht Treaty under the third pillar and the rulings of the Court of Justice in the cases on environmental crime and ship-source pollution which paved the way for criminalization under the former first pillar, ${ }^{32}$ the Union legislator continued to use the internal market legal basis of the first AML Directive in the adoption of the second and third AML Directives, both adopted after the entry into force of the Amsterdam Treaty. ${ }^{33}$ The post-Lisbon fourth AML Directive is no exception. It has been adopted under the internal market legal basis of Article 114 TFEU, with the text of the fourth AML Directive continuing to state that money laundering (and terrorist finance) must be prohibited (and not criminalized). ${ }^{34}$

This choice is all the more striking in view of the abolition of the third pillar and the introduction of an express 'functional criminalisation' EU competence in Article 83(2) TFEU, under which the Union has the power to adopt legislation defining criminal offences and imposing criminal sanctions when such measures are essential to ensure the effective implementation of a Union policy in an area which has been subject to

31 Articles 57(2) and 100(A) EC, now Articles 47(2) and 95 TFEU respectively. For an analysis of negotiations and outcome, see V. Mitsilegas, Money Laundering Counter-measures in the EU, p. 56-63.

32 Case C-176/03 Commission v. Council, EU:C:2005:542 ( the environmental crime ruling); and Case C-440/05 Commission v. Council, EU:C:2007:625 ( the ship-source pollution ruling). For an analysis see V. Mitsilegas, 'The Transformation of Criminal Law in the Area of Freedom, Security and Justice', 26 Yearbook of European Law 2007 (2007), p. 1-32.

33 V. Mitsilegas, Money Laundering Counter-Measures. V. Mitsilegas and B. Gilmore, 56 International and Comparative Law Quarterly (2007).

34 Article 1(2) of the second AML Directive. 
harmonization measures. ${ }^{35}$ The choice of the Union legislator to disregard the express criminal law legal basis of Article 83(2) TFEU and base the fourth AML Directive solely on Article 114 TFEU is also at odds with a number of other EU criminal law measures with a financial law dimension post-Lisbon. One example has been post-Lisbon secondary law on market abuse, where two parallel instruments - one on administrative and one on criminal law - have been adopted. ${ }^{36}$

Another example has been the proposed directive on criminalizing fraud against the Union budget. Whereas the European Commission has opted in favour of exclusively using Article 325 TFEU as a legal basis ${ }^{37}$ in negotiations in the Council Member States have opted for the use of Article 83(2) TFEU as the sole legal basis for this instrument. ${ }^{38}$ The choice to use or not to use Article 83(2) TFEU is not merely symbolic. Using Article 83(2) TFEU has constitutional implications including the granting to Member States of the possibility of triggering an emergency brake in negotiations, the nonparticipation of Denmark in the adoption of the instrument and the possibility of an opt-out for the United Kingdom and Ireland. ${ }^{39}$ The use of Article 114 TFEU as the sole legal basis for the fourth AML Directive ensures maximum participation by EU Member States in its provisions.

\section{B. THE EXPANSION OF THE MONEY LAUNDERING PREDICATE OFFENCES}

As mentioned above, the evolution of EU anti-money laundering law has been characterized by a constant extension of the list of money laundering predicate offences. Article 3(4) of the fourth AML Directive includes as predicate offences terrorism, drug trafficking, organized crime, fraud, corruption and all offences which are punishable

35 V. Mitsilegas, 'EU Criminal Law Competence After Lisbon: From Securitised to Functional Criminalisation', in D. Acosta and C. Murphy (eds.), EU Security and Justice Law (Hart, 2014), p. 110129.

36 Regulation (EU) No 596/2014 of the European Parliament and of the Council of 16 April 2014 on market abuse (market abuse regulation) and repealing Directive 2003/6/EC of the European Parliament and of the Council and Commission Directives 2003/124/EC, 2003/125/EC and 2004/72/EC, [2014] OJ L 173/1; and Directive 2014/57/EU of the European Parliament and of the Council of 16 April 2014 on criminal sanctions for market abuse (market abuse directive), [2014] OJ L 173/179.

37 Commission Proposal for a Directive of the European Parliament and of the Council on the fight against fraud to the Union's financial interests by means of criminal law, $\operatorname{COM}(2012) 363$ final.

38 See Council document 8604/15, Brussels, 7 May 2015, from www.statewatch.org/news/2015/may/eucouncil-fraud-dir-trilogue-8604-15.pdf.

39 Indeed, the United Kingdom has raised the issue of Article 83(2) TFEU being included in the legal bases of the proposal, but has not objected to the content or its participation in the Fourth Money Laundering Directive, see House of Lords European Union Committee, The UK's opt-in Protocol: implications of the Government's approach, 9 ${ }^{\text {th }}$ Report, Session 2014-15, HL Paper 136. On the 'intergovernmental' elements of Article 83 TFEU see V. Mitsilegas, 'From Overcriminalisation to Decriminalisation. The Many Faces of Effectiveness in European Criminal Law', 15 New Journal of European Criminal Law (2014). 
by deprivation of liberty or a detention order for a maximum of more than one year or, as regards Member States that have a minimum threshold for offences in their legal system, all offences punishable by deprivation of liberty or a detention order for a minimum of more than six months. It is clear thus that the EU has moved to a model of the criminalization of money laundering on an all-crimes basis. Some of the predicate offences are defined by reference to European Union (terrorism, organized crime, fraud) or United Nations (drug trafficking) criminal law measures in the field. Others however (including corruption, notwithstanding the existence of both EU and international law norms in the field) and other offences falling within the generic penalty threshold definition in Article 3(4)(f) of the fourth AML Directive, however, are not defined by reference to other EU law or international instruments and many of them remain unharmonized at EU level. This choice poses significant challenges to legal certainty, in particular in the operation of EU mutual recognition measures such as the Framework Decision on the European Arrest Warrant, where mutual recognition of judgments related to money laundering must take place without the requirement for executing authorities to verify the existence of dual criminality. ${ }^{40}$

The fourth AML Directive has continued the trend towards the extension of the money laundering predicate offences by expressly including in this list tax offences defined as tax crimes relating to direct taxes and indirect taxes. ${ }^{41}$ This addition raises concerns, particularly since no harmonization of the definitions of tax crimes has taken place at EU level and, as indicated in the Commission proposal for the fourth AML Directive, there was no intention to do so. ${ }^{42}$ As a result, different tax offences may be designated at the national level, potentially affecting the implementation of other rules of the fourth AML Directive.

In its Impact Assessment, the Commission had contended that designing detailed rules for the circumstances in which the offence is committed would be the optimal option, as it would ensure coherence across the EU, send a clear signal with respect to tax crimes and ensure the efficiency of cooperation. ${ }^{43}$ However, it pointed out that it would 'entail substantial delays due to political difficulties in agreeing a common list of types of tax evasion', ${ }^{4}$ thus delaying an overall agreement. Therefore, the Commission opted for an approach whereby the existing threshold applied in serious crimes would

40 Article 2(2) of 2002/584/JHA: Council Framework Decision of 13 June 2002 on the European arrest warrant and the surrender procedures between Member States - Statements made by certain Member States on the adoption of the Framework Decision (European Arrest Warrant Framework Decision), [2002] OJ L 190/1.

$41 \quad$ Article 3(4)(f) of the fourth AML Directive.

42 See the Commission Proposal for a Directive on the prevention of the use of the financial system for the purpose of money laundering including terrorist financing, COM(2013) 45 final, p. 14

43 Commission Impact Assessment accompanying the proposal for a Directive on the prevention of the use of the financial system for the purpose of money laundering including terrorist financing and the proposal for a Regulation on information accompanying transfers of funds, SWD(2013) 21 final, p. 39. Ibid. 
be used without the adoption of a precise definition. The Parliament favoured a different approach by noting that 'agreeing on a definition of tax crimes is an important step in detecting those crimes', without however, providing any suggestions on such a common definition. ${ }^{45}$

In the light of these concerns, the Council proposed to include in Recital 11 of the fourth AML Directive a reference pointing out the different definitions of tax offences at the national level and noting that 'while no harmonisation of the definitions of tax crimes (...) is sought, Member States, should allow, to the greatest extent possible under their national law, the exchange of information or the provision of assistance between EU Financial Intelligence Units (FIUs)'. ${ }^{46}$ The express insertion of tax offences within the Union's anti-money laundering framework may lead to a catch-all, undifferentiated crime control strategy which fails to distinguish between the distinct features and rationale behind the criminal and regulatory response to tax offences on the one hand and serious and organized crime on the other. As in the case of the introduction of terrorist finance within the Union's anti-money laundering framework, this approach may prove to be ineffective by utilizing anti-money laundering tools for tackling a very distinct phenomenon. From a criminal law perspective, this development may have seriously adverse labelling implications. ${ }^{47}$ The catch-all approach of the fourth AML Directive - which seems to have adopted a purely functionalist model of criminalization by inserting tax predicates in order to ensure maximum intelligence sharing - would thus undermine key principles of criminal law.

\section{THE RELATIONSHIP BETWEEN CRIMINAL AND ADMINISTRATIVE LAW}

In addition to the prohibition of money laundering as such, EU anti-money laundering law has introduced sanctions for non-compliance with the money laundering preventive duties imposed by the AML Directives upon the private sector. The AML Directives leave considerable discretion to Member States regarding the types and levels of sanctions they can use, something which is confirmed also by the fourth AML Directive. ${ }^{48}$ However, the fourth AML Directive goes a step further than its previous incarnations. Article 59

$45 \quad$ Council of the European Union, Document 7387/14, 13.3.2014, p. 11.

46 As already agreed in Council of the European Union, Document 9752/1/12, 26.5.2014, p. 5.

47 According to Alldridge and Mumford, differentiation of tax evasion from other acquisitive crimes is important for the purposes of the labelling function of criminal law. If all acquisitive crime is redesigned as tax evasion, then the ability of the criminal law to differentiate when labelling is diminished, see P. Alldridge and A. Mumford, 'Tax Evasion and the Proceeds of Crime Act 2002', 25 Legal Studies (2005), p. 353-373, 372-373.

48 According to Article 58(1) of the fourth AML Directive, Member States must ensure that obliged entities can be held liable for breaches of national provisions transposing this Directive in accordance with this Article and Articles 59 to 61. Any resulting sanction or measure shall be effective, proportionate and dissuasive. 
of the fourth AML Directive stipulates that in certain cases sanctions must be applied. In particular, cases of serious, repetitive, systematic breaches or a combination of these concerning customer due diligence, suspicious transaction reporting, record-keeping or internal controls must be subject to sanctions. The EU legislator went a step further by including a list of minimum penalties for such cases: a public statement; ${ }^{49}$ an order requiring the specific conduct to stop; withdrawal or suspension of authorization (where appropriate); a temporary ban from exercising managerial functions in obliged entities; and a maximum administrative pecuniary sanction of at least twice the amount of the benefit derived from the breach or at least $€ 1,000,000$. For breaches concerning a credit institution or financial institution, the maximum pecuniary penalties for a legal person are at least $€ 5$ million or $10 \%$ of the total annual turnover, and at least $€ 5$ million for a natural person. Finally, the requirement that Member States produce statistical data is reinforced and refined by enlisting types of data that need to be compiled at the national level. ${ }^{50}$

A key question with broader policy and constitutional implications concerns the relationship between criminal and administrative sanctions in this field. Article 58(2) of the fourth AML Directive states that national rules on administrative sanctions implementing the fourth AML Directive will be without prejudice to the right of Member States to provide for and impose criminal sanctions, adding that Member States may decide not to lay down rules for administrative sanctions or measures for breaches which are subject to criminal sanctions in their national law.

However, it is questionable whether this lack of harmonization contributes towards the effectiveness of EU law in the field. If the choice of the EU legislator has been to treat non-compliance with the preventive duties set out in the fourth AML Directive by administrative sanctions, then the choices of Member States to 'goldplate' implementation by imposing criminal sanctions should be limited by the requirement to ensure the effectiveness of EU law. Effectiveness in this context is not necessarily linked to criminalization, and, as with other post-Lisbon cases (including in particular the market abuse legislation), effectiveness of EU law may actually lead to de-criminalization, rather than over-criminalization. ${ }^{51}$

49 The EDPS has highlighted that the publication of sanctions is not in line with necessity and proportionality rules and is not coupled with adequate safeguards for the rights of the individuals in question. See Opinion of the European Data Protection Supervisor (EDPS) on a proposal for a Directive of the European Parliament and of the Council on the prevention of the use of the financial system for the purpose of money laundering and terrorist financing, and a proposal for a Regulation of the European Parliament and of the Council on information on the payer accompanying transfers of funds, 4.7.2013, https://secure.edps.europa.eu/EDPSWEB/webdav/site/mySite/shared/Documents/ Consultation/Opinions/2013/13-07-04_Money_laundering_EN.pdf, p. 12-13.

50 Article 44 of the fourth AML Directive.

51 V. Mitsilegas, 15 New Journal of European Criminal Law (2014), p. 415-424. 


\section{\$4. THE PREVENTION OF MONEY LAUNDERING}

The imposition of a series of preventive duties upon the private sector constitutes the cornerstone of any anti-money laundering regime. The co-opting of the private sector by the state in the fight against money laundering is a key example of what David Garland has called the responsibilization strategy. ${ }^{52}$ In the case of money laundering, this strategy has been promoted by the FATF, and implemented in detail by the EU. Key duties of the private sector in this context constitute customer identification, record keeping, reporting of suspicious transactions and the duty not to 'tip off' customers or other relevant persons in money laundering investigations. ${ }^{53}$

The imposition of preventive duties on the private sector has evolved over time in two respects. Firstly, the revision of FATF Recommendations and subsequent amendments of the EU AML Directives have expanded the scope of the professions which are subject to anti-money laundering preventive duties, from banks and financial institutions initially to other regulated professions such as lawyers and accountants, to less regulated sectors including 'other persons trading in goods to the extent that payments are made or received in cash in an amount of EUR 10000 or more, whether the transaction is carried out in a single operation or in several operations which appear to be linked'. ${ }^{54}$ The extension of anti-money laundering preventive duties to less regulated sectors raises serious questions of the feasibility of compliance and effectiveness of prevention in sectors of limited regulation and resources.

The extension of the list of professions covered by money laundering legislation has created controversy in particular regarding the imposition of preventive duties to lawyers, with the latter arguing that these duties are contrary to the relationship of trust between lawyer and client and challenge the rights of fair trial and protection of private and family life.

Since the adoption of the second AML Directive, there have been attempts to balance conflicting interests by covering notaries and independent legal professionals primarily in the context of financial transactions. ${ }^{55} \mathrm{EU}$ law exempts them from the second AML Directive's duties when they ascertain the legal position of their clients or they represent their clients in legal proceedings. ${ }^{56}$ It has also done so by allowing Member States to designate an appropriate self-regulatory body other than the FIU to receive suspicious transaction reports.

\footnotetext{
52 D. Garland, 'The Limits of the Sovereign State', 36 British Journal of Criminology (1996), p. 445-471.

V. Mitsilegas, Money Laundering Counter-measures, Ch. 5.

Article 2(1)(e) of the fourth AML Directive. See also a further extension provided by Article 4(1) of fourth AML Directive on the risk-based approach.

55 See Article 1(3)(b) of the fourth AML Directive.

56 See Article 34(2) of the fourth AML Directive.
} 
Both the Court of Justice and the European Court of Human Rights have ruled that such EU law ${ }^{57}$ complies with the right to fair trial ${ }^{58}$ and the right to privacy ${ }^{59}$ respectively. It is noteworthy in this context that the European Court of Human Rights has in effect legitimized the role of the FATF in developing anti-money laundering standards and in assessing Member States' anti-money laundering performance. ${ }^{60}$ The Court noted in particular in response to the claimant's argument that the imposition of duties on lawyers was ineffective that this was not the case since the FATF found that France's methods of combating money laundering and the financing of terrorism were among the most effective in the world. ${ }^{61}$

The second feature in the development of anti-money laundering preventive duties has been the elaboration in greater detail and sophistication of the content of these duties. Two seemingly conflicting trends can be discerned in this context. On the one hand, the categories of individuals and companies to be monitored under know-your-customer and due diligence requirements have proliferated, to include expressly and in greater detail, as will be seen below, beneficial owners and politically exposed persons. On the other hand, a prescriptive approach focusing on routine compliance with preventive duties - including for example the routine reporting of suspicious transactions if they exceed a certain threshold - has been replaced by the adoption of a so-called 'risk-based approach' to compliance. ${ }^{62}$

The adoption of a 'risk-based approach' can be seen as an attempt to move from mechanical compliance to a system where the quality of compliance - and in particular customer due diligence and suspicious transaction reports - is enhanced. As has been noted, in the risk-based approach, cooperation becomes active and dynamic as professionals must design an anti-money laundering model which is suited to make the use of financial structures and networks more difficult for money launderers. ${ }^{63}$ While it remains to be seen whether the 'risk-based approach' will lead to a more effective anti-money laundering framework, it must be noted that by granting a greater degree of discretion to the private sector, it may create a greater degree of legal uncertainty for those called upon to comply with the preventive anti-money laundering duties. The extent to which the adoption of a risk-based approach would constitute a defence or exonerate the private sector from administrative or criminal liability for alleged non-

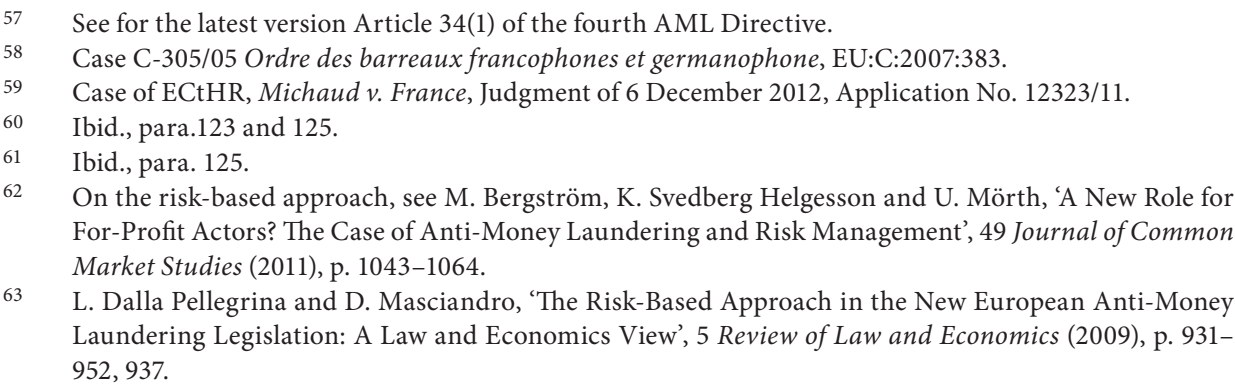

63 L. Dalla Pellegrina and D. Masciandro, 'The Risk-Based Approach in the New European Anti-Money Laundering Legislation: A Law and Economics View’, 5 Review of Law and Economics (2009), p. 931952, 937. 
compliance with preventive anti-money laundering duties is not particularly clear. The fourth AML Directive has further developed both these trends (on the extension of the web of monitoring while at the same time employing a risk-based approach) and the main new features will be examined below.

\section{A. THE EXTENSION OF PREVENTIVE DUTIES RATIONE PERSONAE}

The first extension of the scope of the fourth AML Directive involves the gambling industry. According to Article 2(1)(f) of the fourth AML Directive, the requirement for applying customer due diligence is extended to the whole gambling sector, and no longer to casinos only as was the case since the second AML Directive. ${ }^{64}$ However, following an appropriate risk assessment, Member States may decide to exempt in full or in part providers of certain gambling services from the rules on the basis of a proven low risk posed by the nature and, where appropriate, the scale of operations of such services. Among the factors for such a risk assessment, Member States must consider the degree of vulnerability of the applicable transactions. Furthermore, any decision must be notified to the Commission together with a justification of the specific decision, including the extent to which the Commission reports have been taken into account. ${ }^{65}$

This requirement, which goes beyond the FATF Recommendations, was deemed as necessary since national laws had already addressed the broader risks associated with other forms of gambling. ${ }^{66}$ Consequently, from the point of view of the Commission, the issue at stake was not whether to include the gambling sector as a whole among the obliged entities, but rather whether this inclusion would be the rule, signifying that the gambling activities would be covered unless in cases of a low risk of money laundering, or the exception, entailing that these would be covered only when there is a proven higher risk. ${ }^{67}$

The second extension of the scope of the Directive is found in Article 2(1)(e) of the fourth AML Directive, according to which persons dealing in goods and who receive payment in cash in an amount of $€ 10,000$ or more are also included among the obliged

64 See also Recital 21 of fourth AML Directive.

65 This addition was not included in the Commission proposal. See Council of the European Union, Documents 13215/13, p. 15 and 5786/1/14, 21.2.2014, p. 18. The exclusion of gambling services of low risk was also favoured by the European Parliament. See European Parliament, Legislative Resolution of 11 March 2014 on the proposal for a directive of the European Parliament and of the Council on the prevention of the use of the financial system for the purpose of money laundering and terrorist financing (COM(2013)0045)-C7-0032/2013-2013/0025(COD), as found in Council Document 7387/14, 13.3.2014, p. 30.

66 For example, see Annex IX attached to the Impact Assessment illustrating the different coverage of national laws in relation to casinos and the gambling sector. Commission Impact Assessment accompanying the proposal for a Directive on the prevention of the use of the financial system for the purpose of money laundering including terrorist financing and the proposal for a Regulation on information accompanying transfers of funds, $\operatorname{SWD}(2013) 21$ final.

67 Ibid., p. 45 
entities. ${ }^{68}$ As with gambling activities, the fourth AML Directive is a step ahead of the FATF Recommendations that set the threshold at $€ 15,000$. The rationale was once again found in that a number of Member States had taken a stricter approach towards the requirement for traders to conduct customer due diligence either by applying identification requirements at a lower threshold or by imposing an outright ban on payments in cash above certain thresholds. ${ }^{69}$ Due to this diversity of thresholds, the Commission has received complaints that the proceeds of robberies and thefts committed in one Member State can be anonymously converted into cash in another Member State without the requirement to identify the customer if the amount of the transaction is less than $€ 15,000 .^{70}$

\section{B. PREVENTION: STRENGTHENING THE RISK-BASED APPROACH}

There are three dimensions of risk-assessment and risk-management in the fourth AML Directive: the national dimension; the European Union (European Commission) dimension; and the private sector dimension. Regarding the national dimension, the fourth AML Directive places Member States under the obligation to ensure, in accordance with the risk-based approach, that its scope is extended in whole or in part to professions and to categories of undertakings, other than the obliged entities referred to in its Article 2(1), which engage in activities that are particularly likely to be used for the purposes of money laundering or terrorist financing. ${ }^{71}$ In addition to the obligation to widen the ratione personae scope of the fourth AML Directive following the risk-based approach (which may result in considerable discrepancies in the coverage of various professions from Member State to Member State), Article 7 of the fourth AML Directive places a duty on Member States to identify, assess, understand and mitigate the risks of money laundering and terrorist financing, including any data protection concerns by having in place a mechanism or authority that would organize the national response to the risks identified. Information would be extracted by the Commission reports.

In terms of the Union dimension of risk assessment, according to Article 6 of the fourth AML Directive, the Commission is entrusted with the task of assessing the risks of money laundering and terrorist financing affecting the internal market and relating to cross border activities. Furthermore, with a view to protecting the proper functioning of the internal market, it is an obligation to identify high-risk countries, in terms of

\footnotetext{
68 It is noteworthy that the Commission proposal stipulated a threshold that was even lower, that is $€ 7,500$.

69 For an overview of national practices see Commission, Final Study on the application of the AntiMoney Laundering Directive (conducted by Deloitte, December 2010), p. 74-78.

70 Commission Impact Assessment accompanying the proposal for a Directive on the prevention of the use of the financial system for the purpose of money laundering including terrorist financing and the proposal for a Regulation on information accompanying transfers of funds, SWD(2013) 21 final, p. 27. Article 4(1) of fourth AML Directive.
} 
countries that have strategic deficiencies in their domestic anti-money laundering and counter-terrorism framework. The Commission's 'internal' risk assessment tasks in relation to EU Member States are coupled with parallel 'external' risk assessment duties. According to Article 9(1) and (2) of the fourth AML Directive, the Commission must identify third-country jurisdictions which have strategic deficiencies in their national anti-money laundering and counter-terrorist finance regimes that pose significant threats to the financial system of the Union ('high-risk third countries') in order to protect the proper functioning of the internal market. The recent Commission Communication on terrorist financing states that the Commission will accelerate its work under the fourth AML Directive to provide for the identification of third countries with strategic deficiencies in the area of anti-money laundering or countering terrorist financing. ${ }^{72}$

In terms of the private sector dimension of risk assessment, the fourth AML Directive places Member States under the duty to ensure that obliged entities take appropriate steps to identify and assess the risks of money laundering and terrorist financing, taking into account risk factors including those relating to their customers, countries or geographic areas, products, services, transactions or delivery channels. ${ }^{73}$ They must also ensure that obliged entities have in place policies, controls and procedures to mitigate and manage effectively the risks of money laundering and terrorist financing identified at the level of the Union, the Member State and the obliged entity. ${ }^{74}$ In both cases, the measures taken must be proportionate to the nature and size of the obliged entities.

Furthermore, in relation to simplified due diligence measures, the third AML Directive provided for exceptions in cases when the customers were credit or financial institutions. Member States could allow professionals to disapply the measures to companies 'listed on a regulated market' within the scope of Directive 2004/39/ EC, ${ }^{75}$ domestic public authorities, and other customers who represent a low risk of engaging in money laundering or terrorist financing. In addition, customers who are public authorities or bodies could benefit from simplified due diligence under specific conditions. ${ }^{76}$ Articles 15 and 16 of the fourth AML Directive stipulate far stricter rules by abolishing any of the aforementioned automatic entitlements. Instead, decisions on whether to apply simplified due diligence would be based on the low risk characterizing transactions or customer relationships. The European Supervisory Authorities will adopt guidelines as to the risk factors to be taken into

\footnotetext{
72 European Commission, Communication on an Action Plan for strengthening the fight against terrorist financing, $\operatorname{COM}(2016) 50 / 2$, p. 4.

73 Article 8(1) of fourth AML Directive.

74 Article 8(3) of fourth AML Directive.

75 Directive 2004/39/EC of the European Parliament and of the Council of 21 April 2004 on markets in financial instruments amending Council Directives 85/611/EEC and 93/6/EEC and Directive 2000/12/ EC of the European Parliament and of the Council and repealing Council Directive 93/22/EEC, [2004] OJ L 145/1.

76 Article 11 of the third AML Directive.
} 
consideration and the measures to be taken under such circumstances by the end of the implementation period. ${ }^{77}$

\section{THE TARGETS OF MONITORING: POLITICALLY-EXPOSED PERSONS}

In an attempt to strengthen the preventive side of the fourth AML Directive, the definition and treatment of politically exposed persons (PEPs) as potentially risky individuals has undergone significant change. The third AML Directive defined PEPs as the 'natural persons who are or have been entrusted with prominent public functions and immediate family members, or persons known to be close associates, of such persons', ${ }^{78}$ while that Directive required enhanced due diligence measures in relation to those residing in another Member Stare or in a third country. ${ }^{79}$ Similarly, the 2012 FATF Recommendations made a distinction between foreign and domestic PEPs and provided examples of specific positions they may hold in order to fall under each category. Furthermore, risk-based requirements for domestic PEPs were introduced, so that obliged entities would be under different levels of obligation in respect of foreign and domestic PEPs.

The fourth AML Directive departs significantly from the FATF approach and goes beyond the international standards and the existing rules; not only does it drop the differentiation between foreign and domestic PEPs, but also it lists the specific posts that an individual may hold in order to qualify as a PEP in an exhaustive manner ${ }^{80}$ Similarly, clarifications are provided in relation to the terms 'family members' and 'persons known to be close associates' which cannot be found in the FATF Recommendations. ${ }^{81}$ More importantly, the fourth AML Directive prescribes that enhanced due diligence is required for all types of PEPs irrespective of whether they are foreign or domestic. ${ }^{82}$ In the Commission's own words, 'this option would give greater clarity and more consistency to the provisions, while placing the EU ahead of the international standard' ${ }^{83}$ Therefore, instead of a graduated approach, whereby obliged entities would have to assess the risks that domestic PEPs pose on the basis of risk sensitive elements, ${ }^{84}$ the EU legislator

Article 17 of third AML Directive.

Article 3(8) of third AML Directive.

Recital 25 and Article 13(4) of third AML Directive.

See Article 3(9) of fourth AML Directive.

According to Article 3(10) of the fourth AML Directive family members include the spouse, children and their spouses and the parents of PEPs.

82 Article 20 of fourth AML Directive.

83 Commission Impact Assessment accompanying the proposal for a Directive on the prevention of the use of the financial system for the purpose of money laundering including terrorist financing and the proposal for a Regulation on information accompanying transfers of funds, $\operatorname{SWD}(2013) 21$ final, p. 42.

84 This approach may create some confusion to obliged entities, which would need to apply different standards to difference categories of PEPs. Instead, the Commission approach will come at a higher cost for industry, without a corresponding benefit. 
opted for treating PEPs in their entirety as automatically high-risk individuals to which enhanced due diligence should apply. This development is a welcome step as national officials and those appointed by international organizations may be used by money launderers given their prominent status.

\section{THE TARGETS OF MONITORING: BENEFICIAL OWNERS AND THE CHALLENGES TO DATA PROTECTION}

The anti-money laundering preventive framework involves scrutiny of financial transactions in the context of customers' financial or credit institutions as well as other categories of a wide range of other service providers. Such operations necessarily involve processing, including the collection, retention and further transfer of an abundant amount of personal data of customers, which could potentially be used in investigations by law enforcement authorities. As such, the procedures of customer due diligence constitute an interference with the right to privacy and data protection, thus necessitating strict data protection requirements. Before the adoption of the fourth AML Directive, the inclusion of data protection rules was not a matter of concern in the prevention of money laundering and terrorism financing.

In a welcome step towards transparency and the protection of fundamental rights, the fourth AML Directive prescribes numerous data protection safeguards. These safeguards were deemed necessary to accompany a key innovation of the fourth AML Directive, namely the obligation placed upon Member States to ensure that beneficial ownership information is held in a central register in each Member State, for example a commercial register, companies register, or a public register. ${ }^{85}$ The central register must ensure timely and unrestricted access by competent authorities and FIUs, without alerting the entity concerned and also allow timely access by obliged entities when taking customer due diligence measures. ${ }^{86}$

In particular Recital 14 of the fourth AML Directive stipulates that obliged entities must obtain and hold 'adequate, accurate and current information on their beneficial ownership, in addition to basic information such as the company name and address and proof of incorporation and legal ownership'. Beneficial owners are natural persons who ultimately hold or control the customer and/or the natural person on whose behalf a transaction or activity is being conducted. These references point to the direction of the data minimization and data quality principles without being accompanied by a specific list of the documents and data that would be adequate for the purpose of the fourth AML Directive. Furthermore, this information should be centrally stored in a register located outside the company but within each Member State.

\footnotetext{
$85 \quad$ Article 30(3) of fourth AML Directive.

86 Article 30(6) of fourth AML Directive.
} 
In order to address the divided views of Member States on the storage of data so that it can be accessed in a timely manner, the fourth AML Directive allows for ample flexibility in selecting and/or establishing appropriate mechanisms which ensure unrestricted access. ${ }^{87}$ Therefore, Member States may use a central database specifically set up for storing beneficial ownership information, or the business register or another central register. They may also require obliged entities to fill in the register and they should make sure that information is available to competent authorities, FIUs or obliged entities when the latter take customer due diligence measures. In addition, other persons who are able to demonstrate a legitimate interest are granted access to the data. ${ }^{88}$ While full public access is not explicitly foreseen, however, this may take root at the national level since Recital 15 of the fourth AML Directive allows Member States significant leeway to provide for conditions of access that are wider than the provisions of the fourth AML Directive, thus potentially leading to divergent implementation at the national level. ${ }^{89}$ However, Article 30(9) of the fourth AML Directive prescribes that Member States may refuse access to obliged entities or third parties exceptionally and on a case-by-case basis where such access would expose the beneficial owner to the risk of fraud, kidnapping, blackmail, violence or intimidation or where the owner is a minor or otherwise incapable.

Recital 43 and Article 41(2) of the fourth AML Directive include a direct reference to the purpose limitation principle according to which the processing of personal data should be permitted only for the purposes of the Directive. ${ }^{90}$ In addition, the collection and further processing of the data should be limited to what is strictly necessary and data should not be further processed in a way that is incompatible with that purpose. Processing for commercial purposes in particular is strictly prohibited.

Moreover, the retention period of the data appears to be a particularly problematic aspect of the fourth AML Directive. In particular, Recital 44 and Article 40 of the fourth AML Directive provide that obliged entities should maintain the information acquired through due diligence measures as well as records of the transactions for at least five years after the end of the business relationship with their customer or after the date of an occasional transaction. The retention period, however, may be extended by Member

87 Austria in particular favoured a central register and fully public access. See Council of the European Union, Document 10973/14, 13.6.2014, p. 2. See also the reservations by Estonia, Council Document 10973/14 ADD 1, 19.6.2014, p. 1.

88 Council, Document 16775/13, p. 4.

89 The FATF Guidance on beneficial ownership of October 2014 stipulated that such information may be publicly accessible, but recognizes that this may raise and needs to be balanced with privacy concerns. Fully public access was also favoured by the Parliament so that any citizen could access the information of any company in any country. This approach was preferred with a view to contributing to the fight against tax evasion, which however is not included among the objectives of the Directive and would signify a significant function creep. However, such an approach was deemed by a large majority of Member States as disproportionate. See Council of the European Union, Document 16221/14, 2.12.2014, p. $2-4$.

90 It is noteworthy that the Directive enumerates (albeit in a non-exhaustive manner) different activities which involve the processing of personal data. 
States for an additional five years after a thorough assessment of the necessity and proportionality of such further retention and consider it to be justified as necessary for the prevention, detection or investigation of money laundering or terrorist financing.

Finally, such rules are without prejudice to the national criminal law on evidence applicable to ongoing criminal investigations and legal proceedings. The aforementioned rules raise grave proportionality concerns. While a retention period of five years may seem reasonable (although it would have been welcomed if specific arguments had been provided), the possible extension of another five years gives Member States a large amount of leeway. It would have been preferable if the fourth AML Directive provided for a possible extension of the retention period after a careful assessment on a caseby-case basis, as the EDPS had suggested, ${ }^{91}$ or at least for specific guidelines as to the circumstances under which such an extension would be necessary.

Finally, Article 41(3) of the fourth AML Directive refers to the right of information of the individuals concerned providing that prior to the establishment of a business relationship or carrying out an occasional transaction they must be informed about the legal obligation under which obliged entities are. While this is a welcome provision, it is uncertain whether a customer would understand the purpose for which the personal data were collected and retained, in particular whether they would be processed for commercial purposes as well. The right to access to the data is even more worrying. According to Article 41(4) of the fourth AML Directive Member States are allowed to restrict it in order to enable the obliged entity or competent national authority to properly fulfil its tasks or to avoid obstructing official or legal inquiries, analyses, investigations or procedures set out in the Directive. As with other provisions on data protection, it leaves wide discretion to Member States to determine the cases in which a person may not have access to their information.

The right of access prescribed not only in the Data Protection Directive $e^{92}$ but also in Article 8 of the Charter of Fundamental Rights of the EU (the Charter) ${ }^{93}$ and any limitation must be strictly interpreted. The EU legislator should have at least provided some guidelines as to when such limitation would be necessary and proportionate. Also, it should have mentioned that this limitation should be used on an exceptional basis. In this regard, it is noteworthy that the Parliament had allowed some latitude in its report,

91 Opinion of the European Data Protection Supervisor (EDPS) on a proposal for a Directive of the European Parliament and of the Council on the prevention of the use of the financial system for the purpose of money laundering and terrorist financing, and a proposal for a Regulation of the European Parliament and of the Council on information on the payer accompanying transfers of funds, 4.7.2013, https:/secure.edps.europa.eu/EDPSWEB/webdav/site/mySite/shared/Documents/Consultation/ Opinions/2013/13-07-04_Money_laundering_EN.pdf, p. 14.

92 Directive 95/46/EC of the European Parliament and of the Council of 24 October 1995 on the protection of individuals with regard to the processing of personal data and on the free movement of such data, [1995] OJ L 281/31.

93 Charter of Fundamental Rights of the European Union, [2012] OJ C 326/391. 
suggesting that if access is denied by an obliged entity or competent authority, the data subject could have the right to request via the national data protection authority any verifications of, access and corrections to or erasure of his or her personal data, as well as the right to lodge a judicial procedure. ${ }^{94}$

Overall, the data protection rules as formulated in the final text are a significant step forward in comparison to the previous regime. However, a number of issues are left to the discretion of the Member States allowing a great amount of leeway for diverging practices and raising proportionality issues. A final note on the data protection provisions of the fourth AML Directive: according to Article 43 of that Directive, the processing of personal data is considered 'a matter of public interest' under the Data Protection Directive. The extent to which this must be the relevant ground for data processing is doubtful. It appears that a more relevant ground might be the requirement to comply with a legal obligation by the obliged entities, competent authorities and FIUs. ${ }^{95}$

\section{\$5. THE FINANCIAL INTELLIGENCE ASPECT: ELABORATING THE RULES ON THE OPERATION OF FINANCIAL INTELLIGENCE UNITS AND THEIR COOPERATION}

A question which is often left relatively unexplored in the evolution of the global and EU anti-money laundering regime is what happens to personal and financial data (in particular suspicious transaction reports) once they have left the private sector entities who are under the obligation to report. Data supplied by the private sector under antimoney laundering law reaches organizations which are called financial intelligence units. Thus far, EU law has regulated FIUs in a manner of brevity, with few general provisions in the AML Directives and a third pillar Decision on FIU co-operation. ${ }^{96}$ Importantly, EU law has not imposed upon Member States a specific model of FIUs. Hence FIUs have developed organically at national level and have taken many different forms, which can be categorized broadly into four models: police FIUs, administrative FIUs, judicial FIUs and independent FIUs. ${ }^{97}$ These differences in national models of

94 European Parliament, Report on the proposal for a directive of the European Parliament and of the Council on the prevention of the use of the financial system for the purpose of money laundering and terrorist financing, A7-0150-2014, p. 69.

95 Opinion of the European Data Protection Supervisor (EDPS) on a proposal for a Directive of the European Parliament and of the Council on the prevention of the use of the financial system for the purpose of money laundering and terrorist financing, and a proposal for a Regulation of the European Parliament and of the Council on information on the payer accompanying transfers of funds, 4.7.2013, https:/secure.edps.europa.eu/EDPSWEB/webdav/site/mySite/shared/Documents/Consultation/ Opinions/2013/13-07-04_Money_laundering_EN.pdf, p. 8.

96 Council Decision of 17 October 2000 concerning arrangements for cooperation between financial intelligence units of the Member States in respect of exchanging information, [2000] OJ L 271/4.

97 For an early such categorization, see V. Mitsilegas, 'New Forms of Transnational Policing: The Emergence of Financial Intelligence Units in the European Union and the Challenges for Human 
FIUs can be explained by efforts by Member States to accommodate the new preventive anti-money laundering framework within their legal and financial systems. In particular, the placement of FIUs outside the criminal justice sector (preferred in the majority of EU Member States), reflects the view that suspicious transaction reports which are transferred by the private sector to be filtered by FIUs - are not necessarily relevant to criminal proceedings. Hence, keeping reports outside the criminal justice system initially will help safeguard the privacy of affected individuals while creating trust in the system between the regulated and the regulators. This focus towards independence is also reflected in the concessions offered by the AML Directives to legal professionals, with Member States as mentioned above having the option of designating other regulatory bodies (such as bar associations) as recipients of suspicious transaction reports by lawyers.

The fourth AML Directive introduces a number of changes to this framework via a series of detailed provisions. One of the key objectives behind the revision of the EU money laundering framework was to enhance the powers of FIUs, particularly with regard to the cross-border cooperation between them. ${ }^{98}$ Until then, such cooperation was addressed by Council Decision 2000/624/JHA ${ }^{99}$ which concerned arrangements between national FIUs in respect of exchanging information. The third AML Directive merely stated that coordination and cooperation between FIUs, including the establishment of an EU FIU-net, should be encouraged to the greatest possible extent and for that purpose the Commission would provide assistance. ${ }^{100}$ In this context, the proposal aimed at introducing new provisions regarding FIU powers and cooperation, including an explicit legal basis for the matching of anonymous data between the FIUs and clarifying the circumstances under which exchange of information could take place. ${ }^{101}$ It was admitted that while these amendments would not solve all existing difficulties in the exchange of

Rights - Part 1', 3 Journal of Money Laundering Control (1999), p. 147-160; V. Mitsilegas, 'New Forms of Transnational Policing: The Emergence of Financial Intelligence Units in the European Union and the Challenges for Human Rights - Part 2', 3 Journal of Money Laundering Control (2000), p. 250-259. A more recent analysis confirms the substance of this categorization: I. Deleanu, 'FIUs in the European Union- facts and figures, functions and facilities', in B. Unger et al. (eds.), The Economic and Legal Effectiveness of the European Union's Anti-Money Laundering Policy (Edward Elgar, 2014), p. 97-124.

98 This was necessary for two reasons; first, to streamline EU legislation with the FATF Recommendations; and secondly, to expressly include terrorist financing within the scope of FIU action. See Commission Impact Assessment accompanying the proposal for a Directive on the prevention of the use of the financial system for the purpose of money laundering including terrorist financing and the proposal for a Regulation on information accompanying transfers of funds, $\operatorname{SWD}(2013) 21$ final, p. 110-111.

99 Council Decision 2000/642/JHA of 17 October 2000 concerning arrangements for cooperation between financial intelligence units of the Member States in respect of exchanging information, [2000] OJ L 271/4.

100 Recital 40 and Article 38 of the third AML Directive.

101 Commission Impact Assessment accompanying the proposal for a Directive on the prevention of the use of the financial system for the purpose of money laundering including terrorist financing and the proposal for a Regulation on information accompanying transfers of funds, SWD(2013) 21 final, p. 4647. 
information domain, they would enhance both legal clarity and the effectiveness of the fight against money laundering and financing terrorism. ${ }^{102}$

\section{A. THE ESTABLISHMENT AND OPERATION OF FIUS}

The fourth AML Directive calls for the setting up of 'operationally independent and autonomous FIUs' at the national level to collect and analyse the information that they receive with the aim of establishing links between suspicious transactions and underlying criminal activity so as to prevent and combat money laundering and terrorism financing. ${ }^{103}$ Recital 37 of the fourth AML Directive (replicated in Article 32(3) of the fourth AML Directive) explains that an operationally independent and autonomous FIU is understood as the unit that 'has the authority and capacity to carry out its functions freely, including the autonomous decision to analyse, request and disseminate specific information'. ${ }^{104}$ The fourth AML Directive requires that suspicious transactions and other information regarding money laundering should be reported to the FIU, which should serve as a central national unit for receiving, analysing and disseminating to the competent authorities the results of its analyses. ${ }^{105} \mathrm{In}$ fact, it is made clear that the duty to report is not dependent on the amount of the transaction. ${ }^{106}$

Moreover, Article 21 of the third AML Directive, referring to the powers and tasks of FIUs has undergone certain modifications. In particular, Article 32(4) of the fourth AML Directive prescribes that FIUs shall be able to respond to requests for information by competent authorities in their respective states, when such requests are triggered by concerns relating to money laundering, associate predicate offences or terrorist financing. ${ }^{107}$ The decision of whether to conduct the analysis or dissemination of information remains with the unit. ${ }^{108}$ However, the EU legislator added two

102 Alternatively, the Commission envisaged the establishment of a single European FIU entrusted with the reception, analysis and dissemination to the competent authorities of the information obtained from obliged entities. Such a system would stumble upon national objections concerning sovereignty. See ibid.

103 Recital 37 and Article 32(3) of fourth AML Directive. It is noteworthy that the proposal did not contain a reference to the need that the FIUs are operationally independent and autonomous. Compare Recital 25 and Article 31(3) of the proposal (Commission Proposal for a Directive on the prevention of the use of the financial system for the purpose of money laundering including terrorist financing, COM(2013) 45 final). The addition in Recital 37 of fourth AML Directive that a FIU should operationally independent and autonomous was proposed by the Council. See Council Document 13215/13, p. 8.

104 The definition of what an operationally independent and autonomous FIU means was inserted at a later stage. See Council of the European Union, Document 10970/14 (General approach), 13.6.14, p. 9.

105 Recital 37 of fourth AML Directive.

106 This clarification was not included in the Commission proposal. See Council of the European Union, Document 16775/13, 22.11.13, p. 8.

107 Compare with Article 31(4) of the proposal (Commission Proposal for a Directive on the prevention of the use of the financial system for the purpose of money laundering including terrorist financing, $\operatorname{COM}(2013) 45$ final) which referred to 'law enforcement authorities'.

108 This addition was proposed by the Council. See Council Document 16775/13, p. 44. 
circumstances under which FIUs will not be obliged to comply with the request for information: a) where there are objective grounds for assuming that the provision of such information would have a negative effect on ongoing investigations or analyses, or, b) in exceptional circumstances, where disclosure of the information would be clearly disproportionate to the legitimate interests of a natural or legal person or irrelevant with regard to the purposes for which it has been requested. Another addition is that FIUs are required to provide feedback as how they made use of the information provided and about the outcome of the investigations or inspections performed on the basis of that information. ${ }^{109}$ Thus, elements of transparency and accountability are inserted in the FIUs powers.

Furthermore, FIUs are empowered to take urgent action directly or indirectly, where there is a suspicion that a transaction is related to money laundering or terrorist financing, to suspend or withhold consent to a transaction that is proceeding, in order to analyse the transaction, confirm the suspicion and disseminate the results of the analysis to the competent authorities. ${ }^{110}$ In this regard, the Council added that the FIU shall be able to take such action even when that was requested by an FIU established in another Member State on the basis of the national law of the FIU receiving the request. ${ }^{111}$

In addition, a new rule regarding the analysis function of the FIU is introduced. This function will consist of an operational analysis which focuses on individual cases and specific targets or on appropriate selected information, depending on the type and volume of the disclosures received and the expected use of the information after dissemination and of a strategic analysis addressing money laundering and terrorism financing trends and patterns. ${ }^{112}$ Finally, minor additions have been inserted in Article 22 of the third AML Directive concerning the duties of obliged entities with regard to FIUs. First, obliged entities are mandated to inform the FIU about suspicious transactions including by filing a report and in such cases there is an explicit duty to promptly respond to requests by the FIU for additional information. ${ }^{113}$

\section{B. COOPERATION BETWEEN FIUs}

The improvement of exchange of information between FIUs across the EU is placed high in the hierarchy of measures to address money laundering and terrorist financing. In this context, special reference is made to the decentralized computer network FIU.et or its successor and the techniques offered by it. ${ }^{114}$ Furthermore, Recital 55 of the fourth

\footnotetext{
109 Article 32(6) of fourth AML Directive. This requirement was inserted by the Council. See Council Document 13215/13, p. 37.

110 Article 32(7) of fourth AML Directive.

111 Council, Document 13215/13, p. 38.

112 Article 32(8) of fourth AML Directive.

113 Article 33 of fourth AML Directive. Emphasis added.

114 Recital 56 of fourth AML Directive.
} 
AML Directive highlights the role of the EU Financial Intelligence Unit Platform (EU FIUs Platform), an informal group composed of representatives from FIUs, which has been active since 2006. ${ }^{115}$ Moreover, in the light of the extension of predicate offences to include tax crimes, it is clarified that the exchange of information on cases concerning tax crimes should be without prejudice to the exchange of information taking place on the basis of Directive 2011/16/EU or in accordance with international rules concerning tax matters. ${ }^{116}$ Finally, Recital 58 is a new addition to the fourth AML Directive in comparison to the Proposal and sets out certain basic rules as to how FIUs' cooperation should take place: in particular, Member States should encourage their competent authorities to provide (rapidly, constructively and effectively) the widest range of crossborder cooperation for the purposes of the fourth AML Directive. More importantly, the fourth AML Directive mandates free, spontaneous or upon request, information exchange between FIUs established in the EU and third-country financial intelligence units, having regard to EU law and to the principles relating to information exchange as developed by the Egmont Group of FIUs. ${ }^{117}$

Moving to the core of the Directive, Article 51 of the fourth AML Directive refers to the role of the Commission within the FIU cooperation framework. In order to facilitate coordination, including information exchange, the Commission is enabled to convene regular meetings of the EU FIU's platform composed of representatives from Member States' FIUs. The addition of this article in comparison to the previous regime lies in the extensive references to the work of the platform, as also highlighted in Recital 55 of the fourth AML Directive. It is mentioned in this regard that it may facilitate cooperation among FIUs, exchange views and provide advice on implementation issues relevant for FIUs and reporting entities as well as on cooperation-related issues such as: effective FIU cooperation; the identification of suspicious transactions with a cross-border dimension; the standardization of reporting formats through the FIU.net platform or its successor; the joint analysis of cross-border cases and the identification of trends and factors relevant to assessing the risks of money laundering; and terrorist financing at national and supranational level. ${ }^{118}$

As regards the coordination between FIUs as such, it needs to be stressed at the outset that the fourth AML Directive requires Member States to ensure that FIUs cooperate with each other 'to the greatest extent possible' irrespective of the model they have chosen for their organization. ${ }^{119}$ Overall, the EU rules regarding exchange of information are highly favourable towards information exchange and provide very limited restrictions

\footnotetext{
This Recital was added in Council Document 13215/13, p. 19.

Recital 56 of fourth AML Directive.

To a large extent this recital was added by the Council. See Council Document 16775/13, p. 12. Ibid., p. 56.

Article 52 of fourth AML Directive. In this regard, the European Parliament had suggested specific reference to the need to ensure compliance with data protection rules. See Council of the European Union, Document 7387/14, 13.3.14, p. 67.
} 
in this regard. In particular, according to Article 53(1) of the fourth AML Directive, FIUs are empowered to exchange, spontaneously or upon request, any information that may be relevant for the processing or analysis of information by the FIU related to money laundering or terrorist financing, 'even if the type of predicate offence that may be at stake is not identified at the time of the exchange'. ${ }^{120}$ In terms of the procedure, Article 53(1) of the fourth AML Directive further sets out the necessary elements that a request for information exchange should contain, namely the relevant facts, background information, reasons for the request and how the information sought will be used. In order to ensure extensive cooperation, different exchange mechanisms may be used if so agreed between the FIUs, in particular as regards exchanges through the FIU.net platform or its successor. ${ }^{121}$ Besides, in cases when a report concerns another Member State, then the FIU must promptly forward it to the FIU of that Member State. ${ }^{122}$

The permissive approach of the Directive as regards cooperation between FIUs is further attested in Article 53(2) of the fourth AML Directive, according to which FIUs must be able to use the whole range of their available powers that they would normally use domestically for receiving and analysing information when it applies to a request for information from another FIU. Then the request should be replied to in a timely manner and if a FIU requests additional information from an obliged entity established in another Member State which operates on its territory, the request should be addressed to the FIU of the Member States in whose territory the obliged entity is established. ${ }^{123}$

Perhaps the most notable example of the wide possibilities for information exchange offered by the Directive can be found in Article 53(3) of the fourth AML Directive. The latter prescribes the conditions under which a FIU may refuse to disclose information on the basis of a request. In principle, it must be stressed that, as Recital 56 of the fourth AML Directive suggests, requests for exchange of information should normally be approved. ${ }^{124}$ It is only in exceptional circumstances where the exchange of information could be contrary to fundamental principles of its national law that the requested FIU may refuse to exchange information. ${ }^{125}$ In order to ensure this practically free and unlimited information exchange between FIUs, the fourth AML Directive further requires Member States to formulate those exceptions in a way which prevents misuse of, and undue limitation on, the free exchange of information for analytical purposes.

\footnotetext{
120 This last part of this sentence was added by the Council. See Council Document 16775/13, p. 56.

121 The inclusion of this sentence was suggested by the Council. See Council Document 13215/13, p. 49.

122 Ibid.

123 The inclusion of this rule was at the behest of the European Parliament. See Council Document 7387/14 p. $68-69$.

124 In Recital 56 of fourth AML Directive it is stated that 'the initial exchange of information between FIUs relating to money laundering or terrorist financing for analytical purposes which is not further processed or disseminated should be permitted unless such exchange of information would be contrary to fundamental principles of national law'.

125 Article 53(3) of fourth AML Directive.
} 
In this regard it is noteworthy that in comparison with the Commission proposal, this provision was significantly watered down by Council during negotiations. ${ }^{126}$ In particular, the Commission envisaged far stricter conditions for refusal to exchange information either: a) when divulging information would lead to impairment of a criminal investigation being conducted in the requested Member State; or b) in exceptional circumstances, understood as where divulgation of information would be clearly disproportionate to the legitimate interests of a natural or legal person of the Member State or irrelevant to the purposes for which it has been collected. In addition, the proposal noted that any such refusal must have been appropriately justified to the FIU requesting the information. ${ }^{127}$ In practice, the Commission proposal mirrored the conditions under which the FIU would be under no obligation to comply with a request for information by the competent national authorities. However, in the light of the final text, the fourth AML Directive creates an interesting paradox; information exchange between FIUs is subject to more lenient conditions than in cases where FIUs have to respond to requests for information by the competent authorities at the national level. More importantly the term 'fundamental principles of national law' is not further elaborated, is particularly vague and may result in divergent interpretations during implementation at the national level.

Moreover, Article 54 of the fourth AML Directive provides rules concerning the aftermath of information exchange. In this regard, it is stated that when exchanging information and documents, the transmitting FIU may impose restrictions and conditions for the use of that information, with which the receiving FIU must comply. In addition, it is explicitly pointed out that the exchanged information must be used only for the purpose for which it was sought or provided, thus making a direct reference to the purpose limitation principle. ${ }^{128}$ As for dissemination of information by the receiving FIU to any other authority, agency or department, or any use of information for purposes beyond the ones for which exchange of information was originally approved, it is subject to the consent of the FIU providing the information. The Commission proposal, which referred to the 'approval' by the requested FIU rather than its 'consent', ${ }^{129}$ included no further guidelines as regards the conditions under which such consent would be provided and the EDPS was overall satisfied with the provision. ${ }^{130}$

\footnotetext{
126 See Council Document 16775/13, p. 57

127 Article 50(3) of the proposal (Commission Proposal for a Directive on the prevention of the use of the financial system for the purpose of money laundering including terrorist financing, $\operatorname{COM(2013)} 45$ final). Article 55(1) of fourth AML Directive. The reference to the purpose limitation principle was added by the Council. See Council Document 16775/13, p. 57.

129 Article 51 of the proposal (Commission Proposal for a Directive on the prevention of the use of the financial system for the purpose of money laundering including terrorist financing, COM(2013) 45 final).

130 Opinion of the European Data Protection Supervisor (EDPS) on a proposal for a Directive of the European Parliament and of the Council on the prevention of the use of the financial system for the purpose of money laundering and terrorist financing, and a proposal for a Regulation of the European
} 
However, during the negotiations, Article 55 of the fourth AML Directive was expanded to further circumscribe the conditions under which the requested FIU would not provide its consent. As with cooperation between FIUs in general, the EU legislator envisages dissemination of information 'to the largest extent possible'. In this framework, the only circumstances under which a requested FIU is allowed to refuse providing its consent for further dissemination, which must be appropriate explained when applicable, are the following: a) where this would fall beyond the scope of its anti-money laundering and terrorist finance provisions; b) where it could lead to an impairment of a criminal investigation; c) where it would be clearly disproportionate to the legitimate interests of a natural or legal person or the Member State of the requested FIU; or d) where it would otherwise not be in accordance with fundamental principles of national law of that Member State. ${ }^{131}$

In addition, the fourth AML Directive mandates Member States to require their FIUs to use protected channels of communication between themselves and encourage the use of the FIU.net platform or its successor. ${ }^{132}$ Besides, FIUs must cooperate by applying state-of-the-art technologies pursuant to national law. These technologies will enable FIUs to match their data with other FIUs in an anonymous way by ensuring the full protection of personal data with the aim to detect subjects of the FIU's interests in other Member States and identify their proceeds and funds. However, the EDPS had recommended that the retention period of the data exchange is defined and limited to what is strictly necessary in relation to the purpose of the processing, that data should be updated by designating agents responsible for this task inside the FIU and that rules should be inserted to ensure the security of data. ${ }^{133}$

\section{CHALLENGES FOR PRIVACY AND DATA PROTECTION}

The aforementioned rules regarding the cooperation between FIUs pose significant challenges concerning the protection of fundamental rights, in particular privacy and data protection, of the individuals whose data is processed. Worryingly, the fourth

Parliament and of the Council on information on the payer accompanying transfers of funds, 4.7.2013, https:/secure.edps.europa.eu/EDPSWEB/webdav/site/mySite/shared/Documents/Consultation/ Opinions/2013/13-07-04_Money_laundering_EN.pdf, p. 22.

131 Article 55(2) of fourth AML Directive. Added by Council Document 16775/13, p. 58.

132 Compare Article 53(1) of the proposal (Commission Proposal for a Directive on the prevention of the use of the financial system for the purpose of money laundering including terrorist financing, $\operatorname{COM}(2013) 45$ final), which uses less strong language by requiring Member States to 'encourage their FIUs to use protected channels of communication'.

133 Opinion of the European Data Protection Supervisor (EDPS) on a proposal for a Directive of the European Parliament and of the Council on the prevention of the use of the financial system for the purpose of money laundering and terrorist financing, and a proposal for a Regulation of the European Parliament and of the Council on information on the payer accompanying transfers of funds, 4.7.2013, https://secure.edps.europa.eu/EDPSWEB/webdav/site/mySite/shared/Documents/Consultation/ Opinions/2013/13-07-04_Money_laundering_EN.pdf, p. 22. 
AML Directive mandates the almost unlimited exchange of information on suspicious transactions irrespective of the organizational nature of the FIU, an issue that has always been left to the discretion of Member States. ${ }^{134}$

First of all, this flexibility as regards the structure of national FIUs and consequently their relationship with the police and judicial authorities signifies that the applicable data protection framework is debatable. An illustration of the problem would be in cases when the requesting FIU is a police authority and the requested is an administrative one. According to Recital 37 of the fourth AML Directive, the purpose of FIUs is 'to collect and analyse the information which they receive with the aim of establishing links between suspicious transactions and underlying criminal activity in order to prevent and combat money laundering and terrorist financing'. Therefore, the purpose of FIUs is directly related to the prevention and fight of specific crimes and as such it should fall within the Article 3(2) exception of the Data Protection Directive, according to which the latter does not apply 'to processing operations concerning public security defence, State security (...) and the activities of the State in areas of criminal law'.

This exception triggers the application of the Framework Decision 2008/977/JHA on exchange of information in criminal matters, soon to be replaced by a directive on the processing of data for criminal law purposes. ${ }^{135}$ Given the function of FIUs as filtering information before this could be further disseminated to law enforcement authorities if necessary, this direction may seem more appropriate. However, this solution is not as straightforward as it may seem: for instance, the EDPS had called for a clarification that FIUs are not considered 'competent authorities' within the meaning of Article 87 TFEU. In the view of the EDPS, '[d] espite the fact that they may have tasks similar to those of law enforcement authorities, they should - in the activities covered by the proposed fourth AML Directive - not be considered as police or judicial authorities'. ${ }^{136}$ The fact that this suggestion was not followed up during the negotiations and the wording of the final text according to which the fourth AML Directive 'is without prejudice to the protection of personal data processed in the framework of police and judicial cooperation in criminal matters, including Council Framework Decision 2008/977/JHA', may be seen as further indications of the true nature of FIUs as forming part of national law enforcement arsenal.

134 For an analysis see V. Mitsilegas, 3 Journal of Money Laundering Control (1999), p. 147-160; and V. Mitsilegas, 3 Journal of Money Laundering Control (2000), p. 250-259.

135 Political agreement has been reached in this regard and the most recent version of the Directive can be found in Council Document 5463/16, 28.1.2016.

136 Opinion of the European Data Protection Supervisor (EDPS) on a proposal for a Directive of the European Parliament and of the Council on the prevention of the use of the financial system for the purpose of money laundering and terrorist financing, and a proposal for a Regulation of the European Parliament and of the Council on information on the payer accompanying transfers of funds, 4.7.2013, https://secure.edps.europa.eu/EDPSWEB/webdav/site/mySite/shared/Documents/Consultation/ Opinions/2013/13-07-04_Money_laundering_EN.pdf, p.6-8. 
Bringing the operation of FIUs into the realm of law enforcement has two consequences: first, under the current regime, only the cooperation of FIUs falls within the scope of the Framework Decision because the latter does not regulate the processing of personal data at the domestic level. This leaves the operation of FIUs within the national territory outside the remits of special EU rules (only the Charter safeguards are applicable in this context). It is after the adoption and implementation of the revised Data Protection Directive that the processing of data both at the national level and EU level will be regulated. Second, the applicability of the Framework Decision signifies that the data protection standards for individuals are heavily watered down in comparison to the 1995 Data Protection Directive. The most prominent example in this regard is the possibility to process exchanged data for purposes other than the ones for which the data had originally been collected. According to Article 3(2) of the Framework Decision,

further processing for another purpose shall be permitted in so far as a) it is not incompatible with the purposes for which the data were collected; b) the competent authorities are authorised to process such data for such other purpose in accordance with the applicable legal provisions; and c) processing is necessary and proportionate to that other purpose.

However, even so Article 55(1) of the fourth AML Directive on the possibility to further disseminate information obtained from an FIU seems to be particularly problematic in so far as it mandates that the requested FIU must grant its consent for further dissemination of data from the requesting FIU to another agency, authority or department, to the extent possible. First of all, the article does not specify the type of authorities to which the information will be disseminated and therefore it is not explicitly stated that these should receive information only insofar as they are allowed to process FIUs' data. Secondly, even in cases when the receiving authorities may process FIUs' information (for example, police authorities that further investigate a suspicious transaction), the necessity and proportionality condition of the Framework Decision is not adequately respected by the fourth AML Directive. Instead of necessity and proportionality assessment being central in any decision for further dissemination, the threshold in the fourth AML Directive is significantly higher; proportionality is one of the four conditions for refusal to grant consent. Besides, it is only when such dissemination is clearly disproportionate to the legitimate interests of the person concerned or the Member State of the requested FIU that consent shall be refused.

These privacy and data protection concerns are exacerbated by recent calls by the European Commission to Member States to improve exchange of financial intelligence between EU FIUs and third country FIUs and between FIUs and the private sector, in line with FATF Recommendations and best practices. ${ }^{137}$ The Commission notes in this context that international standards now emphasize the importance of extending the

137 European Commission, Communication on an Action Plan for strengthening the fight against terrorist financing, $\operatorname{COM}(2016) 50 / 2$, p. 4. 
scope of the access to the information available to FIUs and this will be achieved through an amendment of the fourth AML Directive. ${ }^{138}$ This is familiar territory: in the name of a renewed threat (in this case terrorism), the Commission calls for a revision of a - in this case quite recent - AML Directive in order to implement global (and in particular FATF) standards.

However, the transfer of everyday personal data to third countries on a large scale without a substantive assessment of the adequacy of their data protection framework has been found by the Court of Justice to be contrary to the Charter of Fundamental Rights. ${ }^{139}$ Moreover, the establishment of further information exchange channels between FIUs and the private sector may challenge the principle of purpose limitation and exceed the powers allocated to FIUs. A detailed privacy and data protection audit must accompany any expansion of EU law in the field, in particular taking into account the lack of harmonization in relation to the nature, powers and tasks of FIUs.

\section{\$6. CONCLUSION}

The analysis in this article has painted a picture of a multi-layered, constantly evolving and expanding European Union anti-money laundering legal framework. In all four main pillars of EU anti-money laundering law, measures have been regularly revised and their scope has widened. In the field of criminalization, we have witnessed the proliferation of predicate offences and the conflation within the anti-money laundering framework of the quest to tackle phenomena as disparate as terrorist finance and tax evasion. In the field of prevention, successive EU directives have expanded the list of the professions who are covered by the fourth AML Directive to gradually include nonfinancial and non-regulated professions. At the same time rules on the substance of preventive duties have been further elaborated to both pay particular attention to certain categories of individuals including politically exposed persons and beneficial owners, and to introduce a so-called 'risk-based approach' to prevention. In the field of financial intelligence, EU law - and in particular the fourth AML Directive - has introduced more detailed rules on the operation of financial intelligence units, with their establishment however still firmly grounded on national law.

Throughout the evolution of EU anti-money laundering law, the impact of globalization on EU action - and in particular of the Recommendations of the FATF - has been striking. In all cases mentioned above, EU law has been revised to take into account developments in the FATF Recommendations. The more these standards develop in this manner, however, the more likely it is for the EU legislator to face constitutional and fundamental rights objections. Key examples in this context constitute the recent calls

\footnotetext{
$138 \quad$ Ibid, p. 7.

139 See Case C-362/14 Schrems, EU:C:2015:650.
} 
for the expansion of co-operation between financial intelligence units and the extension of confiscation powers, which may fall foul of national constitutional provisions, the ECHR and the Charter of Fundamental Rights. This landscape demonstrates the limits of the normative outcome of a single agenda, technocratic and expert organization such as the FATF within the broader European Union constitutional context. The tension between attempts to extend the field of enforcement in money laundering law, justified as responding to FATF Recommendations and security threats on the one hand, and upholding constitutional provisions and fundamental rights on the other, is ongoing and will not go away. As the Commission's recent Action Plan on terrorist finance has demonstrated, anti-money laundering law will always be used in a chameleon manner, adjusted to provide ready responses to every security threat arising in the political vocabulary. 